\title{
Yumuşak Gücün Tesis Edilmesinde Kültürel Diplomasinin Önemi ve Bir Uygulayıc1 Olarak Yunus Emre Enstitüsü̈
}

\section{Ahmet Nafiz Ünalmış**}

Öz

$\mathrm{Bu}$ makalede yumuşak gücü meydana getiren unsurlardan kamu diplomasisi ve onun bir uygulama alanı olarak kültürel diplomasi, kavramsal açıdan incelenmiştir. Yumuşak güç kaynakları arasında yer alan kültürel diplomasinin ve Yunus Emre Enstitüsü’nün faaliyetlerinin Türkiye açısından öneminin vurgulanması, bu makalenin amacını teşkil etmektedir. Bu bağlamda çalışmada öncelikle yumuşak güç ve kültür arasındaki ilişki, yumuşak gücü tesis etmede kültürün önemi üzerinden açıklanmaya çalısılııștır. Diğer taraftan yakın tarihte kamu diplomasisi uygulama usullerinin değişmesiyle kültürel diplomasinin bu alanda ortaya çıkan önemi anlatılarak Türkiye'nin başta kamu diplomasisi olmak üzere kültürel diplomaside kamusal düzeyde gösterdiği gelişim, Yunus Emre Enstitüsünün faaliyetleri üzerinden değerlendirilmiştir. Makalede, Yunus Emre Enstitüsü’nün kuruluş süreci anlatılmış, kültürel diplomasiye yönelik faaliyetleri sayısal verilerden yararlanılarak incelenmiş ve 2023 vizyonu doğrultusunda kültürel diplomasiyle ilgili hedeflerine yer verilmiştir.

\section{Anahtar Kelimeler}

Kamu diplomasisi, kültürel diplomasi, yumuşak güç, Soğuk Savaş, dış politika.

\footnotetext{
Geliș Tarihi: 27 Aralık 2018 - Kabul Tarihi: 13 Mayıs 2019

Bu makaleyi şu şekilde kaynak gösterebilirsiniz:

Ünalmış, Ahmet Nafiz (2019). "Yumuşak Gücün Tesis Edilmesinde Kültürel Diplomasinin Önemi ve Bir Uygulayıcı Olarak Yunus Emre Enstitüsü”. bilig - Türk Dünyası Sosyal Bilimler Dergisi 91: 137-159.

${ }^{* *}$ Dr., Ankara/Türkiye

ORCID ID: https://orcid.org/0000-0001-5043-6396

nafizunalmis@gmail.com
} 


\section{Giriş}

Diplomasi, günümüzde sadece devletlerin ve diplomatların dış politikada istediği sonuca ulaşabilmesi için yürüttüğü resmî bir görev olmaktan çıarak, halkların ve sivil yapıya sahip örgütlerin aktör olarak dâhil oldukları bir sürece dönüşmüştür. Sivil unsurların diplomasideki rolünün artması, halkların kültürel niteliklerinin de bu alanda etkinlik kazanmasına imkân sağlamıştır. Bu minvalde kültürel diplomasi; 19. yy. ile beraber devletler açısından kurumsal düzeyde önem kazanmıştır. Kültürel değerlere bir ülkenin sınırları dışında etkinlik kazandırılması da kültürel diplomasinin görev alanı hâline gelmiştir. Kültürel diplomasiyi ciddiye alan devletler, bu alanda güçlenmek ve devlet politikalarını senkronize biçimde devam ettirmek için çeşitli enstitüler kurarak varlık gösterme çabası içine girmiştir. 1980’lerin sonuna gelindiğinde kültürel diplomasi de dâhil olmak üzere tüm kamu diplomasisi faaliyetlerinin, devletlere uluslararası alanda istediğini elde etmeye yönelik kazandırdığı güç, Joseph Nye tarafından soft power olarak adlandırılmıştır. Böylece bu alanda ülkelerin gösterdiği başarı da tıpkı askerî ve ekonomik güç gibi somutlaşmıştır. Türkiye, bu gerçekliği Avrupa ülkelerine göre geç fark etmiş, özellikle kültürel diplomasi alanında 2009 yılında faaliyete geçen Yunus Emre Enstitüsü ve 2010 yılında kurulan YTB (Yurtdışı Türkler ve Akraba Topluluklar Başkanlığı) ile uluslararası alanda varlık göstererek yumuşak güç kapasitesini arttırmaya dönük girişimlerde bulunmuştur.

Türkiye, yumuşak güç olarak tanımlanan güç parametreleri açısından oldukça önemli bir potansiyele sahiptir. Başta Yunus Emre Enstitüsü olmak üzere, çeşitli kamu kurumlarının bu alanda uyum içerisinde çalışması, Türk dış politikasını hedeflerine ulaşıırma anlamında ciddi bir seçenek olarak ortaya çıkmaktadır. Joseph Nye'nın da belirttiği gibi yumuşak gücü sadece bir imaj, halkla ilişkiler yöntemi ve bir popülerlik sorununa indirgemek rasyonel bir yaklaşım değildir. Yumuşak güç de nihayetinde bir güç türüdür ve ülkelerin dış politikada istediği sonuçları elde etmelerine yarayan bir araçtır (Nye 2004: 129). Bu bağlamda ülkeler tıpkı sert güçte olduğu gibi, yumuşak güce sahip olmaya yönelik birbirleriyle rekabet halindedir. Bu alanda üstünlük sağlayan ülkeler incelendiğinde, yumuşak gücü meydana getiren unsurlardan kültürü ve kültürel diplomasiyi son derece etkili kullandıkları anlaşılmaktadır. Bu durum yumuşak güç ve kültür arasındaki ilişkinin önemini ortaya çıkarmaktadır. 


\section{Yumuşak Güç Kavramı ve Kültür İlişkisi}

Soğuk Savaş, her alanda olduğu gibi dış politikaya ilişkin kavramlar üzerinde de kayda değer etkiler meydana çıkarmıstır. 1980’lerin sonuna gelindiğinde Soğuk Savaş’n bitme sürecinde, Joseph Nye bir devletin diğer devlete zor kullanmadan istediğini yaptırmasını yumuşak gü̧̧ olarak tanımlanmıştır. Nye’a göre yumuşak güç; istenilen bir şeyi karşı tarafı etkileyerek elde etmek veya maddi olmayan etkilerle istenilen davranış sonucuna güç kullanmadan ulaşmaktır (Nye 2004: 5-13). Yumuşak gücün kavramsallaştırılması dış politikada güç olgusuna maddi unsurların yanı sıra, kültür vb. şekilde maddi olarak tanımlanması zor unsurların dâhil edilmesini de kolaylaştırmıştır (Kavoğlu 2018: 27). Bundan dolayı Nye, ülkelerin yumuşak güç araçları arasına; sanat, eğitim, popüler kültür, kültürel etkileşim, turizm, karşlıklı temaslar ve ülke içerisinde yürütülen siyasi geleneği yerleştirmiştir (Nye 2004: 5-13). Nye’a göre bir ülkenin sahip olduğu kültür, başka ülkelerce cazip bulunduğu ölçüde yumuşak gücüne katkı sağlar (Yılmaz 2018: 11-39). Politikada yumuşak gücü meydana getiren kaynaklar çoğunlukla bir ülkenin kendi kültürünün ifade ettiği değerlerden, politik alandaki uygulamalarından ve diğer ülkelerle ilişkilerini yürütme şeklinden meydana gelmektedir (Demir 2012: 59). Yumuşak gücü meydana getiren unsurlar, sahip olan ülke açısından tarihsel sürekliliğin sonucunda ortaya çıkmaktadır. Diğer bir ifadeyle ülkelerin siyasi rejimleri yumuşak güçlerini etkilemekte, siyasi rejimlerin ortaya çımasına zemin hazırlayan kültürel yapılar ise kısa sürede değişiklik göstermemektedir. Bu bağlamda ülkelerin sosyal ve siyasal geçmişleri mevcut siyasi rejimin oluşmasında veya yumuşak güç potansiyelinin açığa çıkmasında etkili olmaktadır. 20. yüzyılın başlaması ile beraber uluslararası sistemde ideolojilerin egemen hale gelmesi, radyo-televizyon-internet gibi kitle iletişim araçlarının yaygınlık kazanması, toplumların yumuşak güce yönelik ilgisini arttırmıştır. Yumuşak gücün en önemli uygulayıcıları arasında hükümet dışı organizasyonlar, sivil toplum kuruluşları, küresel şirketler ve medyanın yanı sıra günümüzde gelişen sosyal medya ve her türlü enformasyon teknolojisi yer almaktadır.

Esasında, devletlerin sahip oldukları yumuşak güç unsurları, yumuşak gücün kavramsallaştırılmadığı dönemde de etkili bir politika aracı olmuştur. Yumuşak güç, Soğuk Savaş döneminde akademik olarak tanımlanmamış olsa da $A B D$ ve Rusya arasında sert gücün yanında kullanılmıştır. Bu dönemde kültürel diplomasi, çatışan kutupların birbirlerine karşı kullandıkları bir silah hâline gelmiş ve genellikle propaganda amacıyla kullanılmıştır (Purtaş 2013: 3). Neticede ABD ile Rusya arasında uzun süre devam eden 
Soğuk Savaş sürecinin, ABD’nin üstünlüğü ile son bulmasında yumuşak gücün büyük bir etkisinin olduğu düşünülmektedir (Sancak 2016: 65). Soğuk Savaş sonrası Türkiye de bağımsızlığını kazanan Orta Asya devletleri ile yürüttüğü ilişkilerde klasik diplomasinin yanı sıra kültürel diplomasiyi kullanmıştır. Türkiye, doksanlı yıllarda yürüttüğü kültürel diplomasi faaliyetleri sayesinde bugün Orta Asya'da eğitimden sanata, sağlıktan tarıma birçok alanda sahip olduğu yumuşak gücün etkilerini hissedebilmektedir (Önal 2018: 43). Bu bağlamda Türkiye'nin Orta Asya devletlerine yönelik yürüttüğü ilişkiler SSCB’nin yeni dağıldığı 1991-2000 arası ve 2000 sonrası olmak üzere iki ayrı dönem altında değerlendirilebilir. Türkiye 90’lı yıllarda kendi potansiyelini iyi değerlendiren ve Rusya'yı dışlamayan bir anlayış çerçevesinde bölge ülkeleriyle ekonomik iş birliği alanları yaratarak yumuşak gücünün etkilerini sürdürme çabası içerisine girmiştir. Özellikle bölge ülkelerinden Türkiye’ye yüksek öğrenim görmek için gelen öğrencilere verilen burslar ve bölge ülkelerinde açılan kültür merkezleri, bu doğrultuda devam ettirilmiştir. Türkiye, bölgede genel manada; siyasi ve akademik düzeyde temasların genişletilmesi, karşılıklı gezilerin arttırılması, Türk dili konuşan ülkelerin işleriyle ilgilenecek ayrı bir ajansın kurulması, bölgesel ulaşım ve enerji projelerinin uygulanmasına yoğunlaşmıştır (Önal 2018: 59).

Ülkelerin kültürel yönlerini yumuşak güç kaynakları arasında gören Joseph Nye'a göre Amerika’nın sahip olduğu popüler kültür, ABD için hatırı sayılır düzeyde bir yumuşak güç kaynağıdır. Farklı ülkelerden gelip ABD’de eğitim gören milyonlarca insan, yürütülen akademik ve bilimsel değişim programları, Amerikan kültürünü yayarak ABD'nin yumuşak gücünün artmasında önemli rol oynamıştır (Nye 2004: 44). Öte yandan ABD'nin sahip olduğu sinema endüstrisi, merkezi ABD'de bulunan ve tüm dünyaya yayılan restoran zincirleri, Amerika'daki eğitim olanakları, ABD'nin dış politikada istediği hedefe ulaşmasına yardımcı olan kültürel cazibe unsurları olarak belirmektedir.

"University of Southern California Center on Public Diplomacy ve Portland" adlı STK’nın ortaklaşa yaptırdığı 25 ülkeden 10.500 kişinin (farklı ülke deneyimi bulunan) katıldığı ankette yöneltilen sorulara göre 2017 yılı itibariyle Fransa, yumuşak güç sıralamasında en güçlü ülke seçilirken Türkiye listeye son sıradan girmiştir. Yapılan anketlerde yumuşak gücü meydana getiren unsurlar ayrı ayrı sınıflandırılmıştır. Buna göre hükümet etme, girişimcilik, iş birliği, dijitalleşme, eğitim ve kültürün oluşturduğu altı farklı yumuşak güç unsurunun hiçbirinde Türkiye ilk onda yer alamazken ABD, 
2017 yılında kültür alanında birinci gelmiştir. Yumuşak gücü meydana getiren tüm unsurların genel toplamında 2017 yılında en güçlü seçilen Fransa ise kültür alt başlığında İngiltere'nin arkasından üçüncü sırada yer almıştır (The Soft Power 2017: 39). Aynı kuruluşun 2018 yılında benzer yöntemler kullanarak yaptırdığı anketlerde Türkiye yumuşak güç açısından en güçlü ilk otuz ülke arasına giremezken birinciliği İngiltere almış, kültürel alanda ise ABD yine birinci gelmiştir (The Soft Power 2018: 44).

Yumuşak güç kapasitesine yönelik anketlerde de görüldüğü üzere, ABD’nin yumuşak güç unsurlarından kültürel alanda üst üste birinci gelmesi, bu alandaki üstünlügünü ispat etmektedir. ABD'nin kendi kültürel değerlerini yaymaya yönelik çabaları, zaman içinde yumuşak güç açısından diğer ülkelerin önüne geçmesini sağlayan bir etken olarak belirmiştir. Türkiye ise özellikle son on beş yılda yumuşak gücü uluslararası ilişkilerde istediği sonuca ulaşmak için bir araç olarak kullanabileceğini fark etmiş ve bu yönde politikalar üretmeye başlamıştır. Türkiye, geçtiğimiz on beş yılda yumuşak güç kaynakları arasında görülen kamu diplomasisi ve kültürel diplomasiyi yürütmek için çeşitli kurumları hayata geçirerek yumuşak güç kaynaklarını tesis etmede ilerleme kaydetmiştir.

\section{Bir Yumuşak Güç Sağlayıcı Olarak Kamu Diplomasisi ve Türkiye Örneği}

Kamu diplomasisi, kendi ulusunun düşünce ve amaçlarını, kendi kurumlarını, kültürünü ve ulusal hedeflerini yabancı halklara ifade etme hedefi taşıyan bir hükümetin iletişim süreci olarak tanımlanabilmektedir. Ancak bu tanım, çoğunlukla propaganda ile karışma eğilimi içerisine girmektedir. Kamu diplomasisinin özellikle Soğuk Savaş sırasında negatif anlamlar yüklenen propaganda kavramının yerine ortaya çıkarıldığını iddia edenler de mevcuttur. Fakat literatürde kamu diplomasisi kavramına atfedilen anlam çoğunlukla bir hükümetin açıkça yabancı kamuoyu oluşturma, ulusal hedeflere, çıkarlara ve amaçlara ulaşmak için yapılandırılmış doğru bilgiyi yayma girişimidir (Yılmaz vd. 2017: 118). Propaganda da ise belli bir hedef doğrultusunda doğru olmayan bilgiyle veya herhangi bir fikre taraftar kazandırmak saikiyle yapılabilmektedir.

İkinci Dünya Savaşı'ndan önce diplomasi, uluslararası alanda egemen olan devletleri hedeflerken İkinci Dünya Savaşı'ndan sonra gelişen teknolojinin de etkisiyle STK'lar, uluslararası örgütler diplomasinin aktörleri hâline gelmiş; geleneksel diplomasi konsepti değişmiştir (Akçadağ 2014: 2). Kamu diplomasisi kavramı, üzerinde çok fazla tartışma yürütülen ve tek bir tanım 
çerçevesinde mutabık kalınmakta zorlanılan bir kavramdır. Klasik diplomasi, resmî kanallarla yürütülen, ağırlıkla diplomatların ve devlet adamlarının faaliyetlerini içeren bir politika unsuru iken kamu diplomasisi, bunu daha ileriye götürerek STK’ların ve özel kurumların birbirleri arasındaki ilişkilerini, yabancı kamuoyu oluşturma çabalarını, kültürel etkileşim ve bunun gibi birçok sosyal alanı kapsar hâle gelmiştir.

Kamu diplomasisi, geleneksel diplomasiden ayrışarak başka ülkelerin hükümetlerinden ziyade hükümet dışı aktörlerini ve kamuoylarını etkilemeyi amaçlamaktadır. Hedef yalnızca klasik diplomasideki gibi resmi devlet yetkilileri değil, sıradan bireyler ve halklardır. Ülkeler kamu diplomasisi aracılığıyla kendi vatandaşları ve kurumları ile yabancı ülke vatandaşları arasında diyalog geliştirme imkânına sahiptir. Yabancı kamuoylarını haberdar etmek, etkilemek ve bu etkiyi geliştirerek yanlış anlamaların ve önyargıların yol açtığı kargaşayı, sınır ötesi iletişim ortamını şekillendirmek suretiyle gidermek, kamu diplomasisinin başlıca öncelikleri arasında yer almaktadır (Özkan: 4). Özellikle teknolojinin de yardımıyla iletişim olanaklarının artması TV, internet, sosyal medya, radyo gibi unsurları kamu diplomasisinin temel araçları ve iletişim yöntemi olarak ön plana çıkarmanın yanı sıra, ulus markalama, imaj prestij yönetimi, haber yönetimi, bilgilendirme ve tanıtım faaliyetleri de yeni yöntemler olarak belirmiştir (Ekşi 2017: 10). Soğuk Savaş döneminde de devam ettirilen bu yeni nesil diplomasi, 20. yüzyılın sonlarına doğru kurumsallaşarak akademik camianın ilgisine mazhar olmuştur (Telci 2015: 522). Diplomasinin aktörlerinde meydana gelen değişiklikler, devletlerin diplomatik alanda sahip oldukları güç unsurlarını da değiştirmiştir. Kamu diplomasisi uygulamalarında etkin olan devletlerin yumuşak güç kullanımı konusundaki yetenekleri de buna paralel olarak artış göstermektedir. Zaten diplomasi, yumuşak gücü sağlama alanıdır ve bu açıdan diplomasi ve yumuşak güç kavramları birbirlerini tamamlayıcı niteliktedir.

Türkiye, kamu diplomasisine yönelik yapılan bu tanımlamalardan hareketle geçtiğimiz on yıl içerisinde çeşitli kuruluşları hayata geçirerek kamu diplomasisinin değişen niteliklerinden faydalanma yoluna gitmiştir. 2010 y1lında faaliyetine başlayan Başbakanlık Kamu Diplomasisi Koordinatörlüğü, kamu diplomasisi alanında Türkiye açısından önemli bir gelişmeye işaret 
etmektedir. 30 Ocak 2010 tarihinde Resmi Gazete'de yayımlanan 27478 sayılı Başbakanlık Genelgesi ile Başbakanlığa bağlı bir kurum olarak kurulan Kamu Diplomasisi Koordinatörlüğünün görevleri şu şekilde izah edilmiştir:

Uluslararası toplumu etkilemenin ve yönlendirmenin bir aracı olarak kamu diplomasisi ayrı bir önem kazanmıştır. Uluslararası platformlarda ülkemizin uzun süredir maruz kaldığı itham ve sorunlar karşısında haklılığımızı kanıtlamaya yönelik çalışmaların başarıya ulaşabilmesi için kamu diplomasisi yöntem ve araçları ile uluslararası toplumun doğru yönde bilgilendirilmesi gerekmektedir. Kamu diplomasisi yöntemleriyle ülkemizin uluslararası kamuoyu nezdinde saygınlığının artırılmasına yönelik stratejilerin geliştirilerek, ülkemizin dış tanıtım faaliyetlerinin yürütülmesine ilişkin görevler, ilgili mevzuatla çeşitli kamu kurum ve kuruluşlarına verilmiştir. Ancak, ülkesel ve bölgesel sorunların kolayca küresel bir boyut kazandığı günümüzde, özellikle bilgi ve iletişim teknolojilerinde yaşanan gelişmeler, uluslararası alanda ortaya çıkan firsatlar ve tehditler, kamu diplomasisi konusunda görevli kurumlar arasında daha etkin bir koordinasyonu, yakın iş birliğini ve hızlı karar alma süreçlerini zorunlu hale getirmiştir.

$\mathrm{Bu}$ itibarla, kamu diplomasisi alanında yürütülecek çalısmalar ile stratejik iletişim ve tanıtım faaliyetleri konusunda kamu kurum ve kuruluşları ile sivil toplum örgütleri arasında iş birliği ve koordinasyonu sağlamak amacıyla, bir Başbakan Başmüşavirinin uhdesinde Kamu Diplomasisi Koordinatörlügünün oluşturulması uygun görülmüştür. Kamu Diplomasisi Koordinatörlügünün sekretarya hizmetleri Basın-Yayın ve Enformasyon Genel Müdürlüğü tarafından yerine getirilecektir (Resmi Gazete, Kamu Diplomasisi Koordinatörlüğ̈̈ 2010).

Resmi Gazete'de yayımlanan genelgeden de anlaşıldığı üzere Türkiye, küreselleşme sürecinde uluslararası ilişkilerde meydana çıkan iradenin, artık yalnızca devlet temsilcilerinin iradesi olmadığını, kamuoyunun da bu alanda belirleyici rol üstlendiğini, resmi düzeyde benimsediğini bu metinde belirtmiştir (Özkan: 3). Kamu diplomasisine bakışta manifesto değişikliğine gidildiğini ifade eden genelge, aynı zamanda resmî düzeyde yumuşak güç unsurlarını tesis etmenin devletlerin geleceği açısından ne ölçüde önemli ol- 
duğunun anlaşıldığının beyanı niteliğindedir. Başbakanlık Kamu Diplomasisi Koordinatörlügünün kurulmasılla birlikte kültürel diplomasi yürüten Yunus Emre Enstitüsü ve YTB gibi kuruluşlar arasında koordinasyonun ve delegasyonun sağlanması kolaylaşmıştır. Bu bağlamda Türkiye açısından dış politikada kültürel diplomasinin etkinliğinde artış sağlanmıştır.

\section{Kamu Diplomasisi Yöntemi Olarak Kültürel Diplomasi}

Ülkeler tarafından yumuşak güç unsuru olarak kullanılan kamu diplomasisi, bir dönem kamu diplomasisi koordinatörlüğü yapmış İbrahim Kalın’a göre Türkiye'de daha farklı şekilde ele alınmaktadır. Türkiye'nin yumuşak gücü, gerek şekil gerekse içerik bakımından birçok ülkeninkinden farklılık arz etmektedir. Bu farkın temel sebebini Türkiye'nin kendine özgü tarihî tecrübesi ve Orta Asyàdan Balkanlar'a uzanan geniş bir coğrafyada bölgesel dinamikleri harekete geçirebilecek potansiyeli meydana getirmektedir. Kalın’a göre esasında ülkelerin öncelikleri ve kültürel kodları, kamu diplomasisi pratiklerini değiştirmektedir (Kalın 2011: 5-23). Bu alanda bir başka düşünür Nicholas Cull, kamu diplomasisi yaklaşımlarını dinleme, müdafaa, kültürel diplomasi, değişim diplomasisi ve uluslararası yayınlama ve psikolojik savaş olmak üzere 6 grupta sınıflandırmıştır (Cull 2009: 17-24). Cull'un tanımlamış olduğu diplomasi çeşitleri içerisinde kültürel diplomasi, ülkelerin yumuşak gücünü tesis etmede en yaygın şekilde kullandıkları diplomasi türüdür. Kültürel diplomasi kavramına ilişkin sosyal bilimciler arasında farklı yaklaşımlar ve tanımlamalar söz konusudur. Örneğin Milton Cummings, kültürel diplomasiyi farklı milletler arasında fikirlerin enformasyonu ve sanatın paylaşımı olarak görür. Louis Belanger ise kültürel diplomasiyi, dış politikanın kültür, eğitim ve bilimle ilişkisi şeklinde tanımlar. Günümüzde ise kültürel diplomasi, millî hükümetlerden farklı olarak iş adamları, göçmenler, sanatçılar ve daha birçok sivil unsurun kompleks bir alana katılımı ve bunların fikirlerinin resmi kültür politikaları ile uyumlu bir şekilde hareket etmesidir. Hükümet politikalarının ülke kültürünü oluşturan unsurlarla kombinasyonu, kültürel diplomasinin genel çerçevesini çizmektedir. Bu durum pratikte uygulansa da teorik olarak karmaşık bir yapıya sahiptir (Zamorano 2016: 169).

Nye’a göre kamu diplomasisinin üç boyutu vardır. Her üçü de önem teşkil eder ancak farklı oranlarda hükümet bilgisi ve uzun vadeli kültürel ilişkiler 
içerir. Birinci boyut, gündelik krizlerle başa çıkmaya yönelik hazırlıklı olmaktır. İkinci boyut, siyasi bir kampanya veya bir reklam kampanyasındaki gibi basit temalardan meydana gelen stratejik iletişimlerdir. Kamu diplomasisinin üçüncü boyutu ise kültürel diplomasiyi de içinde barındıran eğitim bursları, değişim programları, stajlar, seminerler, konferanslar ve medya kanallarına erişim yoluyla diğer ülkelerdeki önemli kişilerle zaman içerisinde uzun vadeli ilişkilerin yapılandırılmasıdır (Nye 2004: 108-109).

Kamu diplomasisinin en yaygın biçimde kullanıldığı yer, kültürel alandır. Diplomasi içerisindeki kültürel faaliyetler, bazı ülkelerde kamu diplomasisinden bağımsız şekilde değerlendirilerek kültürel diplomasi adı ile belirtilmektedir. Uygulama ve anlam açısından kamu diplomasisi ve kültürel diplomasi arasında iç içelik söz konusudur. Ancak bu hususta yaygın görüş ise kültürel diplomasinin kamu diplomasisinin bir alt türü olduğu yönündedir. Kültürel diplomasinin temel dayanak noktasını, kültürleri arasında benzerlik olan ülkelerin siyasal etkileşiminin daha rahat oluşturulacağ 1 düşüncesi meydana getirmektedir. Bu sebeple bir devlet, etkilemeye çalıştığı ülke ile kültürel alanda yakınlaşarak iki yönlü kültürel ilişki tesis etmeye çalışmaktadır (Sancar 2012: 170-176). Toplumların sahip olduğu kültürün yumuşak güce dönüşmesi için söz konusu kültürün başka toplumlar için çekicilik arz etmesi, vazgeçilmez koşullar arasında yer almaktadır (Önal 2018: 49). Bu dönüşümün sağlanma sürecinde devletlerin kendi toplumlarının kültürünü uluslararası alanda cezbedici hâle getirmeye dönük politikaları da son derece etkilidir. Diğer taraftan kültürel diplomasi alanında uzmanlaşmış kurumların varlığı bu alanda devletlerin işini kolaylaşıırmaktadır. Türkiye, bu gerçekliği kavradığını Yunus Emre Enstitüsü’nü kurarak göstermiştir.

\section{Yunus Emre Enstitüsü ve Kültürel Diplomasi Alanındaki Faaliyetleri}

Kültürün kamu diplomasisi içindeki önemine erken varan birçok ülke, kendi kültürünü dünya üzerinde yaymaya dönük olarak çalışmalarına devam etmektedir. Bu bakımdan Fransa, İngiltere, Almanya ve Japonya tarafından kurulan çeşitli enstitüler, kamu diplomasisinin en önemli kısmını teşkil eden kültürel diplomasinin uygulayıcıları olarak faaliyet göstermektedir. Kültürel diplomasi alanında faaliyet gösteren bu kuruluşların en önemli amacı, kendi dillerini yurt dışında öğreterek ülke kültürünü yurt dışında yaygınlaştırmak ve bu sayede kamu diplomasisini daha kolay yürütür hale 
gelmektir. Bu kuruluşların yaptığı her türlü eğitim faaliyeti de kültürel diplomasiyi tamamlayıcı mahiyette bir vazife yerine getirmektedir.

Kültürel diplomasinin öneminin farkına vararak bu alanda teşkilatlanmaya başlayan ilk ülke Fransa'dır. 1883 yılında Fransız kültür öğesi olarak açılan Alliance Française, Fransa kültürünü dünyaya tanıtmak amacıyla kurulan ilk organize kültür teşkilatı olarak değerlendirilebilir. İkinci sırada ise 1934 yılında İngilizler tarafından kurulan British Council gelmektedir. İngiliz dili ve kültürünü yaymak amacıyla hayata geçirilen merkez, İngiltere Dışişleri Bakanlığından özerk bir kamu kurumu olarak dünya çapında faaliyet göstermektedir. 1951 yılında Almanyảnın kurmuş olduğu Goethe Enstitüsü ve İspanya tarafından 1991 yılında kurulan Instituto Cervantes, bu iki ülkenin kültürel diplomasi alanında faaliyet gösteren kuruluşları arasında yer almıştır. Bunların dışında diğer ülkeler de 2000'li yıllarla beraber kültür enstitüleri açmaya başlamıştır. 2004 yılında Çin tarafından hayata geçirilen Confucius Institute bunların başında yer almaktadır (Ekşi 2018: 323).

Türkiye ise kültürel diplomaside kamu kuruluşlarının öneminin farkına birçok ülkeye nazaran son derece geç varmıştır. Türkiye, geçtiğimiz on beş yıl içinde gerekli girişimlerde bulunarak kamu diplomasisi ve kültürel diplomasi alanında çeşitli kuruluşları kurmuş ve uluslararası ilişkiler alanında olumlu sonuçlarını görmeye başlamışır. Türkiye, 2009 yılında Yunus Emre Enstitüsü’nü hayata geçirerek kültürel diplomasi yarışına diğer ülkeler gibi kurumsal düzeyde katılım sağlamıştır. Vakıf statüsünde kurulan Yunus Emre Enstitüsü'nün amaçları, 2007 yılında Resmi Gazete'de yayımlanan kanunla detaylı bir biçimde anlatılmıştır. Bu kanuna göre Enstitünün amaçları şu şekildedir:

a) Türkiye'yi, kültürel mirasını, Türk dilini, kültürünü ve sanatını tanıtmak, Türkiye'nin diğer ülkeler ile dostluğunu geliştirmek, kültürel alışverişini artırmak için yurt dışında kültür merkezleri kurulmasını ve işletilmesini sağlamak.

b) Türkiye, kültürel mirası, Türk dili, kültürü ve sanatı konularında yurt dışında ücretli veya ücretsiz eğitim vermek veya verdirmek, bu alanlarda sertifika vermek, verilmesini sağlamak.

c) Türkiye, kültürel miras, Türk dili, kültürü ve sanatına ilişkin yurt içi ve yurt dışındaki bilgi ve belgeleri dünyanın istifadesine sunmak 
için araştırmalar, etkinlikler yapmak veya yaptırmak, yurt içinde ve yurt dışındaki üniversite ve sivil toplum örgütleri, ilgili diğer gerçek ve tüzel kişiler ile ortak projeler yürütmek ve yazılı ve görsel medyada süreli veya süresiz yayınlar yapmak veya yaptırmak.

ç) Yurt dışında benzer kuruluşlar ve uluslararası kuruluşlarla iş birliği yapmak.

d) Yurt içi ve yurt dışında bu Kanunun amacını gerçekleştirmek için araştırma-geliştirme ile ilgili kurum ve kuruluşlarla ve bilgi bankalarıyla iş birliği yapmak, toplanan bilgileri dünyanın istifadesine sunmak, tanıtma büroları, enstitü ve dokümantasyon merkezleri kurmak.

e) Türkiye’yi, kültürel mirasını, Türk dilini, kültürünü ve sanatını tanıtmaya ilişkin etkinlikler hakkında yurt içinde kişi ve kuruluşların bilgilendirilmesi, katılımın sağlanması ve yönlendirilmesi için gerekli çalışmaları yapmak.

f) Bu Kanunun amaçlarını gerçekleştirmek için; Vakfa ve kuruluşlarına sivil toplum örgütlerinin ve üniversitelerin katılımını sağlamak, kültür, sanat, eğitim alanlarında kurulmuş vakıflarla veya derneklerle iş birliği yapmak, bu alandaki akademik çalışmalara aynî veya malî destek sağlamak.

g) Türk dilinin, kültürünün ve sanatının tanıtımına ilişkin yarışmalar düzenlemek ve ödüller vermek.

g) Kültür merkezlerinin kurulmadığı yerlerde bu Kanunun amaçlarının gerçekleşmesi için yurt dışında faaliyet gösteren diğer kamu kurum ve kuruluşları ile birlikte çalışmalar yürütmek (Resmi Gazete, Yunus Emre Vakfı Kanunu 2007)

Yurt dışında 6 milyonun üzerinde vatandaşı bulunan, geçmişte uzun yıllar yönettiği yakın coğrafyasında milyonlarca insanın ve akraba toplulukların yaşadığı Türkiye’nin, Yunus Emre Enstitüsünü kurarak kültürel diplomasinin öneminin farkına varmış olması, Türk dış politikası açısından son derece önemli bir gelişme olarak değerlendirilmektedir. Enstitünün kuruluş kanununda kültürel diplomasinin icra edilmesi için Enstitünün yerine getirmesi gereken görevler, muadili yabancı enstitülerin faaliyetleri de göz önünde bulundurularak belirlenmiştir. 
Yunus Emre Enstitüsü’nün yurt dışında 56 adet kültür merkezi bulunmaktadır. Kültür merkezlerinde verilen Türkçe eğitimin yanı sıra farklı ülkelerdeki eğitim kurumları ile de iş birliği yapılarak Türkçe öğretimi ve Türkoloji bölümlerine destek sağlanmaktadır. Enstitünün 44 ülkede 79 üniversitede uygulanan Türkoloji projesi ile toplamda 60 ülkede 132 irtibat noktası yer alınmaktadır (Yunus Emre Enstitüsü Bülteni 2018: 11). Enstitü, üniversitelerle Türkoloji projesi iş birliği protokolü imzalamak suretiyle mevcut olan bölümleri destekleyerek yeni bölümlerin açılmasını da teşvik etmektedir. Yunus Emre Enstitüsü bu protokol kapsamında Türkoloji ve Türk Dili ve Edebiyatı Bölümlerinde Türkiye'den öğretim elemanı görevlendirmenin yanı sıra materyal ve müfredat desteği de sağlayarak bu bölümlerde daha yüksek nitelikte Türkçe eğitiminin verilebilmesi için çalışmalarına devam etmektedir (Yunus Emre Enstitüsü Faaliyet Raporu 2016: 83).

Yunus Emre Enstitüsü’nün, Türkoloji projesi kapsamında protokol imzaladığı ülkelerin sayısı ve bölgelere göre dağılımı aşağıdaki grafikte verilmiştir:

Resim 1. Yunus Emre Enstitüsü Faaliyet Raporu (2016: 84).

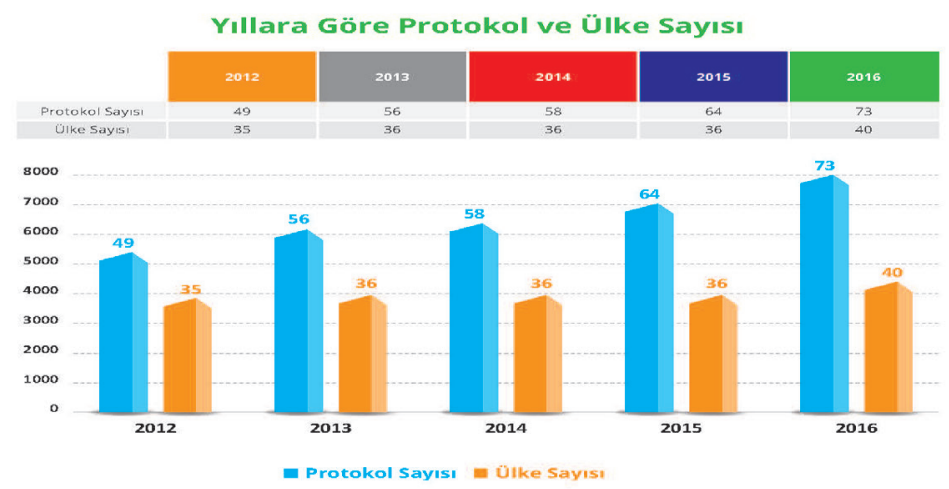

Türkoloji Protokolü Îmzalanan Üniversitelerin ülke ve Bölgelere Göre Dağılımı

\begin{tabular}{|c|c|c|c|c|c|c|}
\hline Avrupa & Balkantar & Orta Doğu & Afrika & Asya & Uxak Doğu & Amerika \\
\hline Belarus & Bosna-Hersek & Fillstin & Cezayir & Afganistan & Japonya & $A B D$ \\
\hline Belçika & Bulgaristan & Irak & Fas & Azerbaycan & & Arjantin \\
\hline $\begin{array}{l}\text { Cek } \\
\text { Cumhuriyeti }\end{array}$ & Hirvatistan & Katar & Misir & $\sin$ & & \\
\hline Estonya & Karadag̈ & Lübnan & Senegal & Endonezya & & \\
\hline |talya & Kosova & Makedorya & sudan & Gurcistan & & \\
\hline Letonya & Romanya & Suudi Arabistan & Mozambik & Hindistan & & \\
\hline Litvanya & Sirbistan & Urdun & Etiyopya & Kazakistan & & \\
\hline Polonya & Moidova & Yernen & Somali & Mogolistan & & \\
\hline Slovakya & & & & Pakistan & & \\
\hline \multicolumn{7}{|l|}{ Ukrayna } \\
\hline 10 & 8 & 8 & 8 & 9 & 1 & 2 \\
\hline
\end{tabular}


Yunus Emre Enstitüsü, kültürel diplomasi alanında dil eğitimi ile ilgili olmak üzere başta kültür merkezlerinde düzenlenen sertifika ve seviye tespit s1navlarının yanı sıra, yabancılara Türkçe öğrenim seviyesinin ölçümünü sağlayan bütün sınavların uygulanması ve hazırlanmasına yönelik faaliyetlerine de devam etmektedir. Türkçe dil seviyesini, uluslararası standartlarda ölçen web ve klasik tabanlı Türkçe yeterlik sınavını uzman kurum ve akademisyenlerle iş birliği yaparak hazırlamaktadır. Enstitü, Türkçe yaz okulu programı kapsamında her yaz yüzlerce öğrenciyi Türkçe öğrenmesi ve Türkiye’yi yakından tanımasını sağlamaya yönelik olarak Türkiye’ye davet etmektedir. Bu kapsamda Enstitü, Türkçe yaz okulu programlarını Türkiye’nin farklı illerinde eğitim veren üniversitelerle koordineli biçimde düzenlemektedir. Türkçe yaz okulu programlarına, yurt dışında faaliyetlerine devam eden Yunus Emre Enstitüleri ve Türkoloji bölümlerinde öğrenim gören öğrenciler katılım sağlamaktadır. Farklı ülkelerden programa davet edilen öğrenciler, aldıkları dil eğitiminin yanı sıra ülkeleri ile Türkiye arasında dostluk köprüleri oluşturmaya yönelik de gönüllü elçilik yapabilmektedir. Enstitünün yaz okulu programlarına katılan öğrenci sayısı, 2010 yılından bu tarafa her yıl artarak devam etmektedir. Bu okullara katılan öğrencilerin \%31'i Balkan ülkelerinden, \%22'si Asya'dan, \%18'i Afrika'dan, \%16'sı Ortadoğu ülkelerinden ve \%13'ü Avrupa ülkelerinden gelmektedir (Yunus Emre Enstitüsü Faaliyet Raporu 2016: 95-97).

Kamu diplomasisinin uzun dönemde stratejik birleşeni sayılan öğrenci değişim programları, ABD başta olmak üzere birçok ülke için ulusal güvenlik açısından da önem arz etmektedir (Trost vd. 2013). Akademik düzeydeki öğrenci değişim programları farklı ülkelerden gelen öğrencilerle geldiği ülke arasında kamusal düzeyde karşılıklı anlayışı yükseltmektedir. Nye'ın da belirttiği gibi farklı ülkelerde eğitim gören insanlar, eğitim gördükleri ülkelerin iyi niyet elçisi gibi davranabilmekte, eğitim gördükleri ülke açısından politik sonuçları olumlu yönde etkileyebilecek mevkilerde çalışabilmektedir. Bu bakımdan Yunus Emre Enstitüsü’nün yürüttüğü eğitim programları, kültürel diplomasinin icra edildiği mecralar arasında yerini almaktadır. Enstitü, kurulduğu tarihten bu yana yaklaşı olarak yüz bin kişiye Türkçe öğretmiş ve kültür sanat faaliyetleri yoluyla milyonlarca kişiye erişim sağlamıştır (Yunus Emre Enstitüsü Bülteni 2018: 11). Enstitü, Türkçeyi zamandan ve mekândan bağımsız olarak öğrenme fırsatı tanıyan Türkçe eğitim portalını da 2017 yılında uygulamaya koymuştur. 159 ülkeden yaklaşık 100.000 kullanıcıya ulaşan dünyanın en büyük Türkçe kursu unvanına sahip olan Türkçe eğitim portalı ile Enstitü, Türkçe öğreterek kültürel etkileşimi artırmayı ve kurum- 
sal kapasiteyi geliştirerek kültürel diplomasi alanında faaliyetlerini genişletmeyi hedeflemektedir (Yunus Emre Enstitüsü Bülteni 2018: 10). Ülkelerin yumuşak güçlerine yönelik yapılan anketlerde İngilizce konuşan ülkelerin ilk 3'e girmesi ve ABD'nin yumuşak güç unsurlarından kültürde üst üste birinci gelmesi, Yunus Emre Enstitüsü’nün Türkçeyi öğretmeye yönelik faaliyetlerinin Türkiye'nin yumuşak gücü açısından ne derece önemli olduğunu ortaya çıkarmaktadır. Yumuşak güç alanında ön sıralarda yer alan ülkelerin Yunus Emre Enstitüsü'ne benzer kurumları çok daha eski tarihlerde hayata geçirdiği dikkate alınacak olursa, Yunus Emre Enstitüsü başta olmak üzere diğer kamu kurumlarının kültürel diplomasi alanındaki faaliyetlerinin Türk dış politikası üzerindeki somut etkisinin kısa dönemde net bir şekilde ölçülmesinin zorluğu da ortaya çıkmaktadır. Türkiye'de eğitim gören ve Türkçe öğrenen nesillerin, ülkelerinde politikaları etkileyebilecek düzeyde yetkin hâle gelmesi zaman alacaktır. Bu bağlamda kültürel diplomasinin etkilerini bugünden yarına ölçmeye çalışmak yerine uzun dönemdeki potansiyelini göz önünde bulundurmanın yararı daha fazladır.

Yunus Emre Enstitüsü, 2023 yılına kadar 100 kültür merkezine ulaşmayı hedeflemektedir. Diğer taraftan Enstitü; Türkoloji projesi kapsamında Türkoloji çalıştayları, Türkoloji alanında çalışan Türkologlarla buluşma programları, sempozyumlar, dil ve kültür eğitim programlarının yanı sıra yazı ve editörlük kursları ve sohbet programları gibi birbirinden farklı faaliyetler yürüterek Türkçenin yurt dışında yaygınlık kazanmasına katkı sağlamaya devam etmektedir. Yunus Emre Enstitüsü, Türkoloji projesi kapsamında iş birliği protokolü imzaladığı üniversitelerle, Yunus Emre Türk Kültür Merkezleri ve Türkiye Araştırmaları Merkezinin bulunduğu yerlere Türkiye'ye yönelik yapılacak çalışmalara kaynak oluşturmak amacıyla Türk dili edebiyatı, tarihi, kültürü ve sanatı alanlarındaki eserlerden müteşekkil 2000 kitaplık 100 kütüphane yapmaktadır. Bu proje ile Türkiye’nin diğer ülkelerle kültürel alışverişinin geliştirilmesinin yanı sıra yurt dışında Türkiye hakkında kaynak meydana getirilmesi amaçlanmaktadır. Kütüphane projesine ilaveten Türkçe köyü, Türkiye kitapçısı, 100 Türkiye çeviri projesi, yerinde tarih projesi ve Merkez Bankasının katkılarıla yapılan ortak resim sergileri, uzaktan Türkçe öğretimi ve Türkiye günleri etkinlikleri, Türk sineması etkinlikleri gibi çeşitli projeler de yürütülmektedir (Ekşi 2018: 342-347).

2000'lerden bu yana Türkiye'ye ve Türkçeye artan ilgi Yunus Emre Enstitüsü’nün dünyanın farklı bölgelerinde açılması taleplerini de gündeme getirmektedir. Genellikle ülkelerden gelen talep üzerine açılan kültür merkezleri, 
dünyaya Türk kültür ve sanatını anlatan bir kurum olarak Türkiye’ye yönelik yanlış bilgilere dayalı ön yargıların giderilmesinde Türk dış politikasına hizmet etmektedir. Bu sayede Enstitü, Türkiye'nin kültürel coğrafyasının inşasına katkı sağlamaktadır (Ekşi 2015: 354).

Yunus Emre Enstitüsü, Bosna Hersek başta olmak üzere Gürcistan, Ürdün ve Romanya’daki eğitim kurumları ile yaptığı anlaşmalar çerçevesinde Türkçenin belirlenen okullarda İngilizceden sonra ikinci seçmeli yabancı dil olarak okutulmasını sağlamıştır. Enstitü, Balkanlarda kültürel mirasın yeniden inşası projesi kapsamında da Bosna Hersek, Makedonya, Arnavutluk, Kosova, Sırbistan, Karadağ ve Hırvatistan'ın içerisinde yer aldığı ülkelerde, savaşlardan tahrip olmuş el yazması eserlerin muhafazası, bakımı ve dijital ortama aktarılması gibi işlemleri yürütmektedir. Bu eserler yeniden hayata kazandırılarak Osmanlı Devleti’nin günümüzde daha iyi anlaşılması sağlanmaya çalışılmaktadır. Bu proje kapsamında özellikle Avrupa ve Balkanlarda artmakta olan milliyetçilik ve yabancı düşmanlığını azaltmak için Osmanlı'nın geçmişte farklı milletleri barış içerisinde yaşatan tarihî tecrübesinden faydalanılması hedeflenmektedir. Enstitü, çeşitli Balkan ülkelerinde hüsnühat, tezhip, minyatür, ebru, cam eşya yapımı, çini ve ahşap iş̧̧iliği vb. alanlardaki el sanatlarına yönelik kurslar açarak burada yaşayan halka meslek edindirmenin yanı sıra Osmanlı'ya dayalı ortak kültür unsurlarının tekrar hayata kazandırılması ve bölge halkı ile Türkiye'nin tarihi ve kültürel bağlarının canlandırılmasını hedeflemektedir (Ekşi 2018: 343-347).

Yunus Emre Enstitüsü, kültürel diplomasi konusunda yurt dışında gerçekleştirmiş olduğu faaliyetlerin yanı sıra yurt içinde de hâlihazırda diplomasi görevini ifa edenlere yardımcı olmak ve ileride görev alacak diplomatların yetiştirilmesine katkı sağlamak amacıyla kültürel diplomasi akademisini hayata geçirmiştir. Bu bağlamda Enstitü, 24 Kasım 2016'dan başlayıp 27 Kasım 2016'ya kadar devam eden "Kültürel Diplomaside Stratejik Analiz Eğitimi" başlıklı bir program düzenleyerek yurt dışında görev yapan Yunus Emre Enstitüsü müdürlerine ilk eğitimini vermiştir. 4 gün süren eğitim ve çalışma programı sınırların dışında düşünmek sloganı ile gerçekleştirilmiştir (Yunus Emre Enstitüsü Faaliyet Raporu 2016: 108-109).

Yunus Emre Enstitüsü, 2023 vizyonunu belirleyerek faaliyet alanlarını daha da genişletmeyi hedeflemektedir. Bu kapsamda kültür, sanat alanında Türkiye'nin son derece zengin bir ülke olduğunu diğer ülkelere hissettirmek, Türkçe öğretimini modern yöntemlerle geliştirmek, Türkolojinin tüm dünyada saygınlığını artırmak, uluslararası alanda çözüm ortaklıklarıyla 
kültürel etkileşime katkı sağlamak ve çağın gereklerine göre yönetim ve organizasyon yapısını şekillendirmek, Enstitünün 2023 vizyonunu meydana getirmektedir. Enstitünün ayrıca kültür sanat vizyonu altında belgesel niteliklerine sahip çeşitli kültür ve sanat faaliyetleri ile Türk kültürünün yurt dışında tanıtılmasını amaçladığı görülmektedir. Çok kültürlülük çerçevesinde diğer toplumlarla ortak noktalara vurgu yaparak hedeflenen kitlelere ulaşılması ve farklı kültürler arasındaki etkileşimin gerçekleştirilmesi, Enstitünün amaçları arasında yer almaktadır. Kültürel diplomasinin en önemli ayaklarından birini teşkil eden dil eğitimi konusunda da Enstitü, kurulmuş ve kurulacak olan merkezler ile yabancı dil olarak Türkçenin öğretimini Avrupa dilleri ortak çerçeve metnine bağlı kalarak uluslararası dil öğretim standartlarına göre geliştirmeyi hedeflemektedir. Bu bağlamda Enstitü, yabancı öğrencilere zamanın gereklerine uygun pedagojik yöntemler ve imkânlarla Türkçe öğretmeyi hedeflemiştir. Yunus Emre Enstitüsü, Türk kültürünün tanıtımına kamu diplomasisinin gereği olarak devam etmekte, bu alanda verimli olabilmek adına da çeşitli çözüm ortaklarıyla birlikte projeler geliştirmeyi planlamaktadır. Enstitü, bu projelerin hayata geçirilmesinde uluslararası fonlardan ve hibe desteklerinden yararlanarak öncü olmayı 2023 vizyonu içerisine yerleştirmiştir. Enstitünün kendi içindeki yapılanmaya dönük hedefleri arasında belirttiği yönetim organizasyon vizyonu ise temelde Enstitünün 2023 vizyonuna uyumlu olacak şekilde güçlü bir alt yapının hayata geçirilmesini hedeflemektedir. Bu kapsamda kurumun ihtiyaçları çerçevesinde en az bir yabancı dili akıcı şekilde konuşabilen ve kültürel diplomasinin gereklerini taşıyabilen kişilerin istihdam edilmesi, kurumun 2023 vizyonu arasında yer almaktadır (Yunus Emre Enstitüsü 2023 Vizyonu 2015: 11).

Enstitü, 2023 vizyonuna dair yayımladığı raporda kurumun misyonunu şu şekilde belirtmiştir: Türkiye'nin kültürel mirasını, Türk dilini kültürünü ve sanatını tanıtmak, Türkiye'nin diğer ülkeler ile dostluğunu geliştirmek, kültürel alışverişini artırmak, bununla ilgili yurt içi ve yurt dışındaki bilgi ve belgeleri dünyanın istifadesine sunmak, Türk dili, kültürü ve sanatı alanlarında eğitim almak isteyenlere yurt dışında hizmet vermek (Yunus Emre Enstitüsü 2023 Vizyonu, 2015: 2). Enstitü, belirlediği misyona yönelik gerek yerel gerekse uluslararası düzeyde örgütlerle iş birliğine giderek kültürel diplomasi alanında faaliyetlerine devam etmektedir. Yunus Emre Enstitüsü, dünyanın farklı bölgelerinde kültürel diplomasi ve kamu diplomasisi alanında faaliyetlerine devam eden enstitülerin pratik ve teorik alanda bilgi paylaşımı sağlanmasına yönelik ikili ve çok yönlü projeler hazırlamak ama- 
cıyla 2014 yılında kurulan küresel kamu diplomasisi ağının üyesidir ve 2017 yılında Türkiye adına bu ağın dönem başkanlığını yürütmüştür (Yunus Emre Enstitüsü Bülteni 2017: 13). Yunus Emre Enstitüsü’ nün gerek günümüzdeki faaliyetleri gerekse vizyonu, bir yumuşak güç kaynağı olarak belirlenen ülke kültürünü dünyada yaygın hale getirmeye dönüktür. Bu bağlamda enstitü, Türkiye'nin farklı ülkelerle ilişkiler geliştirebilmesi ve ittifaklar kurabilmesi için o ülkelerde yaşayan nüfusun Türkiye’ye ve Türk kültürüne yönelik algısını olumlu yönde etkilemeye çalışarak, Türk diş politikasına hizmet etmektedir.

\section{Sonuç}

Ülkelerin sert gücünün dış politikadaki hedeflerine erişmeye yetmemesi, uluslararası alanda farklı güç unsurlarına duyulan ihtiyacı açığa çıkarmıştır. 1980'lerin sonunda Joseph Nye tarafindan kavramsallaştırılan yumuşak güç; eğitim, sanat, ticaret, diplomasi, kültür, hükümet etme, iş birliği gibi birbirinden farklı bileşenlerden meydana gelen çok boyutlu bir faaliyet alanı haline gelmiştir. Bu alanlar arasında kültür, Türkiye’nin sonradan katıldığı yumuşak güç yarışında hızlı yol almasına imkân sağlayabilecek yegâne unsur olarak ön plana çıkmaktadır. Yumuşak güç kaynaklarından kültür olgusu ve bu bağlamda yürütülen kültürel diplomasi, Türkiye açısından değerlendirildiğinde oldukça zengin bir içerikle karşılaşılmaktadır. Türkiye'nin sahip olduğu kültürel aidiyetin izlerinde Osmanlı dokusu ile İslam kültürünün etkisi ön plana çımakta ve bu durum Türkiye'ye Orta Doğu, Orta Asya, Kafkasya ve Balkanlar'da yumuşak gücünü kullanma firsatı sağlamaktadır (Öztop 2018: 143). Bu bağlamda Yunus Emre Enstitüsü’nün başta Türkiye’nin yakın coğrafyası olmak üzere farklı ülkelerle yürüttüğü öğrenci değişim programları, dil eğitimleri ve Türk kültürünün tanıtımına yönelik her türden faaliyeti, Türkiye'nin stratejik düzeyde iletişimine, imajına, marka değerine önemli katkılar sağlayarak Türk Dış politikasının hedeflerine ulaşmasını kolaylaştırmaktadır. Dış ülkelerle Yunus Emre Enstitüsü üzerinden geliştirilen kültürel nitelikli bu mekanizmalar, dış politikada bir araç olarak kullanılan kamu diplomasisinin güç kazanmasına zemin hazırlamanın yanı sıra, Türkiye'nin yumuşak güç potansiyelini de arttırmıştır. Yunus Emre Enstitüsü üzerinden yürütülen kültürel diplomasi, tüm bunların yanı sıra Türkiye nin komşularından kaynaklanan dış politika riskini azaltması için karşılıklı bağımlılık seviyesini artırarak belli bir hareket alanına uygun politik ortamı sağlayabilme potansiyeline de sahiptir. Karşılıklı bağımlılık ilişkisi Ahmet Davutoğlu’nun da belirttiği gibi dış politika projeksiyonu tutarlı olan ülkelerin lehine işleyen mekanizmalar üretmektedir. Ekonomik ve 
kültürel niteliğe sahip bu mekanizmalar siyasi merkezlerden kaynaklanan gerilimleri düşürme ve Türkiye'ye bölgesel güçlere alternatif politikalar üretme imkânı sağlamaktadır (Davutoğlu 2016: 146). Esasen yumuşak gücün kültürel diplomasi aracilı̆̆ıla uzun dönemde tesis edilmesi, ülkenin içinde bulunduğu genel konjonktürle de doğrudan ilgilidir. Türkiye'nin yakın geçmişte yaşadığı Gezi Parkı olayları, 15 Temmuz kalkışması, Rusya ve ABD ile ilişkilerinde yaşadığı gerilimler ve zaman zaman azalış gösterse de sonu gelmeyen terör olayları, ülkenin yumuşak güç unsurlarını tesis etmesi için gerekli siyasal atmosferin oluşumunu engellemekte ve enerjisini içeride yaşanan problemlere yönlendirmektedir. Bu tür olağanüstü durumların yaşanabildiği bir ülke olarak Türkiye'nin, kültürel diplomasi alanında mesafe almış olması, son 15 yıl içerisinde hayata geçirilen diplomasiden sorumlu kamu kuruluşlarının etkinliğinin devam ettiğini göstermektedir.

Kamu diplomasisinin bir uygulama şekli olarak yürütülen kültürel diplomasinin farklı kamu kuruluşları tarafından etkileşim içerisinde yürütülmesi, Türkiye'nin dış politikada hedeflerine ulaşması bakımından önem arz etmektedir. Çünkü Türkiye'nin yumuşak gücünü tesis etmesi, tek bir kuruluşun çabasından ziyade ülkenin bu alanda göstermiş olduğu faaliyetlerin kümülatif toplamından meydana gelmektedir. Kültürel diplomasinin, yurt dışında diaspora ile desteklenmesi ve farklı türden kamu diplomasisi faaliyetlerinde ülke kültürünü oluşturan unsurların tanıtımının yaygın hale getirilmesi, kültürel diplomasiyi tamamlayıcı mahiyettedir. Bu bakımdan Yunus Emre Enstitüsü’nün faaliyetlerinin TİKA, YTB (Yurt Dışı Türkler ve Akraba Topluluklar Başkanlığı), TRT (Türkiye Radyo Televizyon Kurumu), DİB (Diyanet İşleri Başkanlığı), THY (Türk Hava Yolları) tarafından desteklenmesi kültürel diplomaside Türkiye'nin başarısını belirleyici olacaktır. Yumuşak gücü kullanmada başarı göstermiş ülkeler de kurumlar arası koordinasyonu sağlayarak uzun dönemde bu başarıyı yakalamıştır. Türkiye'nin gerek yurt dışında yaşayan vatandaşları gerekse yakın coğrafyası başta olmak üzere farklı yerlerde soydaş ve akraba topluluklarının bulunması, yumuşak güç tesis etme aşamasında, ülkenin karşısına hızlı mesafe almasına imkân sağlayabilecek bir firsat olarak çıkmaktadır. Türkiye'nin, başta kültürel diplomasi olmak üzere yürüttüğü bütün diplomasi dallarında bu gerçekliğin farkındalığıyla hamle yapması gerekmektedir. 


\section{Kaynaklar}

“2017-2018 Stratejik Plan Yunus Emre Enstitüsü”. https:/www.yee.org.tr/sites/ default/files/yayin/2017-2018_staratejik_plan_21.12.2017.pdf (Erişim Tarihi: 23.11.2018).

“2023 Vizyonu Dünya Türkiye’yi Daha Yakından Tanıyor”. https://www.yee.org. tr/sites/default/files/2023_vizyonu.pdf (Erişim Tarihi: 21.11.2018)

Akçadağ, Emine (30/05/2014). Dünya'da ve Türkiye'de Kamu Diplomasisi. http://www.kamudiplomasisi.org/pdf/emineakcadag.pdf (Erişim Tarihi: 26.11.2018).

Cull, Nicholas (2009). Public Diplomacy Lesson From the Past. Figueroa Press.

Davutoğlu, Ahmet (2016). Stratejik Derinlik. İstanbul: Küre Yay.

Demir, Vedat (2012). Kamu Diplomasisi ve Yumuşak Güç. İstanbul: Beta Yay.

Ekşi, Muharrem (2015). "Kültürel Diplomasi ve Yunus Emre Enstitüsü”. Türk Dış Politikası ve Kamu Diplomasisi. Ed. Mehmet Şahin ve Sanem Çevik. Ankara: Nobel Yay. 345-363.

Ekşi, Muharrem (2017). “Türkiye’nin Türk Dünyasına Yönelik Kamu Diplomasisi Yeni Araç ve Mekanizmaları”. Ege Üniversitesi Türk Dünyası Araştırmaları Enstitüsü, Türk Dünyası Incelemeleri Dergisi 17/1 Yaz: 9-19.

Ekşi, Muharrem (2018). Kamu Diplomasisi ve AK Parti Dönemi Türk Dış Politikası. Siyasal Yay.

Kalın, İbrahim (2011). "Soft and Public Diplomacy in Turkey Perceptions". Center For Strategic Research, Perceptions Journal of International Affairs XVI (3): 5-23.

Karadağ, Haluk (2016). Uluslararası İlişkilerde Kamu Diplomasisi. Ankara: Nobel Yay.

Kavoğlu, Samet (2018). Türk Kamu Diplomasisi Halkla İlişkiler Eksenli Model Arayışları. Eğitim Yay.

Nye, Joseph S. (2004.) Soft Power, The Means to Success in World Politics, Public Affairs. New York.

Önal, Buket (2018). “Türkiye’nin Orta Asya’da Uyguladığı Kamu ve Kültür Diplomasisi Politikaları”. Yumuşak Güç ve Kamu Diplomasisi Üzerine Akademik Analizler Türkiye ve Dünyadan Örnekler. Ed. Ayhan Nuri Yilmaz ve Gökmen Kilıçoğlu. Ankara: Nobel Yay. 41-96.

Özkan, Abdullah (t.y.). "21. Yüzyılın Trajik Vizyonu Kamu Diplomasisi ve Türkiye’nin Kamu Diplomasisi İmkânları”. Türk Asya Stratejik Araştırmalar Merkezi Stratejik Raporu No:70. http://www.tasam.org/Files/PDF/ Raporlar/STR70_21._Yuzyilin_Stratejik_Vizyonu.pdf_66fb77c9-cd79481e-a185-9a9c26ffe7b7.pdf (Erişim Tarihi: 24.11.2018). 
Öztop, Fatma Anıl (2018). “Türkiye'nin Suriye Politikasında Yumuşak Güç Kullanımı (2002-2011)”. Yumuşak Gü̧̧ ve Kamu Diplomasisi Üzerine Akademik Analizler Türkiye ve Dünyadan Örnekler. Ed. Ayhan Nuri Yılmaz ve Gökmen Kılıçoğlu. Ankara: Nobel Yay. 135-170.

Purtaş, Fırat (2013). “Türk Dış Politikasının Yükselen Değeri: Kültürel Diplomasi”. Gazi Akademik Bakış 17 (3): 1-14.

Resmi Gazete (2007). "Yunus Emre Vakf1 Kanunu". http://www.resmigazete.gov.tr/ eskiler/2007/05/20070518-3.htm (Erişim Tarihi: 22.11.2018)

Resmi Gazete (2010). "Kamu Diplomasisi Koordinatörlügü Genelgesi”. http:// www.resmigazete.gov.tr/eskiler/2010/01/20100130-19.htm (Erişim Tarihi: 24.11.2018).

Sancak, Kadir (2016). Uluslararası İlişkilerde Güç Kavramı ve Yumuşak Güç. Ankara: Nobel Yay.

Sancar, Gaye Aslı (2012). Kamu Diplomasisi ve Uluslararası Halkla İlişkiler. İstanbul: Beta Yay.

Telci, İsmail Numan (2015). "Yumuşak Güç ve Düşünce Kuruluşları: Türkiye Örneği”. Türk Dış Politikası ve Kamu Diplomasisi. Ed. Mehmet Şahin ve Sanem Çevik. Ankara: Nobel Yay. 519-551.

“The Soft Power 30 A Global Ranking of Soft Power" (2017). https://softpower30. com/wp-content/uploads/2017/07/The-Soft-Power-30-Report-2017Web-1.pdf (Erişim Tarihi: 20.11.2018).

"The Soft Power 30 A Global Ranking of Soft Power" (2018). https://softpower30. com/wp-content/uploads/2018/07/The-Soft-Power-30-Report-2018.pdf (Erişim Tarihi: 20.11.2018).

Trost, Katrina ve Matthew Wallin (2013). Academic Exchange: A Pillar of American Public Diplomacy. Agust, https:/www.americansecurityproject.org/ ASP\%20Reports/Ref\%200135\%20-\%20Academic\%20Exchange\%20 -\%20A\%20Pillar\%20of\%20American\%20Public\%20Diplomacy.pdf (Erişim Tarihi: 20.11.2018).

Yılmaz, Ayhan Nuri (2018). "Kültür ve Sanatın Ulusal Tanınırlığının Pozitifleştirilmesinde Bir Araç Olarak Kullanılması: Türkiye’nin Kültürel Yumuşak Güç Potansiyeli”. Yumuşak Güç ve Kamu Diplomasisi Üzerine Akademik Analizler Türkiye ve Dünyadan Örnekler. Ed. Ayhan Nuri Yılmaz ve Gökmen Kılıçoğlu. Ankara: Nobel Yay. 11-37.

Yılmaz, Ayhan Nuri ve Gökmen Kılıçoğlu (2017). "Balkanlar'da YTB ve TİKA’nın Türk Kamu Diplomasisi Kurumları Olarak Faaliyetleri ve Türkiye’nin Bölgedeki Yumuşak Gücüne Etkileri”. Finans Ekonomi ve Sosyal Araştırmalar Dergisi 2 (2): 115-131.

Yunus Emre Enstitüsü 2016 Faaliyet Raporu. https://www.yee.org.tr/sites/default/ 
files/yayin/2016_faaliyet_raporu_05.02.2018-db.pdf (Erişim Tarihi: 25.11.2018).

Yunus Emre Enstitüsü Bülteni (Eylül-Ekim 2017). https://www.yee.org.tr/sites/ default/files/yayin/bulten_39_turkce_0.pdf (Erişim Tarihi: 24.11.2018).

Yunus Emre Enstitüsü Bülteni (Mart-Nisan 2018). https://www.yee.org.tr/sites/ default/files/yayin/yunus_emre_turkce.pdf (Erişim Tarihi: 23.11.2018).

Yunus Emre Enstitüsü 2023 Vizyonu. https://www.yee.org.tr/sites/default/ files/2023_vizyonu.pdf (Erişim Tarihi 21.11.2018).

Zamorano, Mariano Martín (2016). "Reframing Cultural Diplomacy: The Instrumentalization of Culture under the Soft Power Theory". Culture Unbound 8: 166-186. Published by Linköping University Electronic Press. http://www.cultureunbound.ep.liu.se (Erişim Tarihi: 27.11.2018). 


\title{
The Importance of Cultural Diplomacy to Obtain Soft Power and Yunus Emre Institute as a Practitioner*
}

\author{
Ahmet Nafiz Ünalmış
}

\begin{abstract}
In this article, public diplomacy and cultural diplomacy as a field of application of it which are among the facts that constitute soft power are examined conceptually. The purpose of this article is to emphasize importance of cultural diplomacy which is resource of soft power and activities of Yunus Emre Institute for Turkey. In this context, firstly, the relationship between soft power and culture is tried to be explained by the importance of culture in establishing soft power. In consequence of changes in the procedures for the application of public diplomacy in the recent history, the importance of cultural diplomacy in this area has been discussed and Turkey's development, particularly in public diplomacy, in cultural diplomacy has been evaluated on the activities of the Yunus Emre Institute. In this article, the establishment process of Yunus Emre Institute is explained, and activities of the institute related to cultural diplomacy are examined by using numerical data and through the 2023 vision, the objectives of the institute which is related to cultural diplomacy has been given a place in the study.
\end{abstract}

\section{Keywords}

Public diplomacy, cultural diplomacy, soft power, Cold War, foreign policy.

"Date of Arrival: 27 December 2018 - Date of Acceptance: 13 May 2019

You can refer to this article as follows :

Ünalmış, Ahmet Nafiz (2019). "The Importance of Cultural Diplomacy to obtain Soft Power and Yunus

Emre Institute as a Practitioner”. bilig - Journal of Social Sciences of the Turkic World 91: 137-159.

${ }^{* *}$ Dr., Ankara/Turkey

ORCID ID: https://orcid.org/0000-0001-5043-6396

nafizunalmis@gmail.com 


\title{
Значение культурной дипломатии как «мягкой силы», и деятельность Института Юнуса Эмре*
}

\author{
Ахмет Нафыз Уналмыш **
}

\begin{abstract}
Аннотация
В статье дается концептуальное рассмотрение входящей в число факторов «мягкой силы» публичной дипломатии, и культурной дипломатии как одной из сфер ее применения. Цель данной статьи - подчеркнуть важность культурной дипломатии, которая является одним из источников «мягкой силы», и значение для Турции деятельности Института Юнуса Эмре. В этом контексте, в первую очередь, рассмотрена связь между «мягкой силой» и культурой, а также выявлена важность культуры в формировании «мягкой силы». Кроме того, вследствие изменений в процедурах применения публичной дипломатии в новейшей истории подчёркнута важность культурной дипломатии, и на примере деятельности Института Юнуса Эмре показано развитие публичной дипломатии и культурной дипломатии в Турции. В статье освещается история создания Института Юнуса Эмре, а деятельность института в области культурной дипломатии анализируется с использованием числовых данных; определяются ее цели в контексте концепции «2023».
\end{abstract}

\section{Ключевые слова}

публичная дипломатия, культурная дипломатия, «мягкая сила», холодная война, внешняя политика.

\footnotetext{
* Поступило в редакцию: 27 декабря 2018 - Принято в номер: 13 мая 2019 г.

Ссылка на статью:

Ünalmış, Ahmet Nafiz (2019). "Yumuşak Gücün Tesis Edilmesinde Kültürel Diplomasinin Önemi Ve Bir Uygulayıc Olarak Yunus Emre Enstitüsü". bilig - Журнал Гуманитарных Наук Тюркского Mupa 91: 137-159.

** Д-р., Анкара / Турция

ORCID ID: https://orcid.org/0000-0001-5043-6396

nafizunalmis@gmail.com
} 